\title{
Half-sandwich ruthenium(II)-arene complexes: Synthesis, spectroscopic studies, biological properties and molecular modeling
}

\author{
STEFAN NIKOLIĆ ${ }^{1}$, SANJA GRGURIĆ-ŠIPKA ${ }^{2}$, IVANA S. DJORDJEVIĆ ${ }^{3}$, RAHMA DAHMANI $^{4,5,6}$, \\ DRAGANA DEKANSKI ${ }^{7}$, SAŠENKA VIDIČEVIĆ ${ }^{8}$, JELENA TOŠIĆ $^{8}$, DRAGANA MITIĆ ${ }^{1}$ and \\ SONJA GRUBIŠIĆ* ${ }^{3}$ \\ ${ }^{1}$ Innovative Centre of the Faculty of Chemistry, Studentski trg 12-16, 11000 Belgrade, Serbia \\ ${ }^{2}$ Faculty of Chemistry, University of Belgrade, Studentski trg 12-16, 11000 Belgrade, Serbia \\ ${ }^{3}$ Institute of Chemistry, Technology and Metallurgy, University of Belgrade, Njegoševa 12, 11001 Belgrade, Serbia \\ ${ }^{4}$ Université Paris-Est, Laboratoire Modélisation et Simulation Multi Echelle, MSME UMR 8208 CNRS, \\ 5 Blvd. Descartes, 77454 Marne-La-Vallée, France \\ ${ }^{5}$ Université Tunis El Manar, Faculté des Sciences de Tunis, Unité de Recherche Physico-Chimie \\ des Matériaux à l'Etat Condensé, 2092, Tunis, Tunisie \\ ${ }^{6}$ Laboratoire de Spectroscopie Atomique, Moléculaire et Applications - LSAMA. Université de Tunis El Manar, \\ Tunis, Tunisia \\ ${ }^{7}$ Biomedical Research, R and D Institute, Galenika a d, Pasterova 2, 11000 Belgrade, Serbia R\&D Institute, \\ Galenika a.d., Pasterova 2, 11000 Belgrade, Serbia \\ ${ }^{8}$ Institute of Medical and Clinical Biochemistry, School of Medicine, University of Belgrade, Serbia

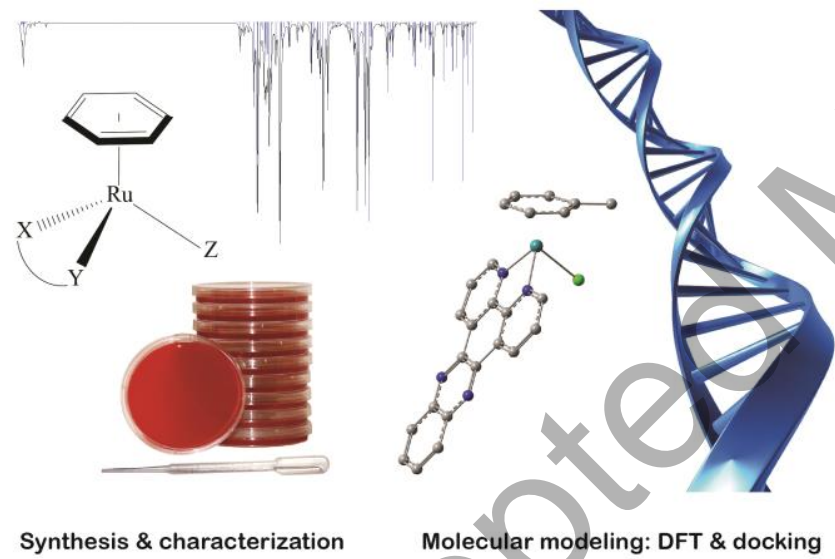

In search for antitumor metal-based drugs that would mitigate the severe side-effects of cisplatin, $\mathrm{Ru}(\mathrm{II})$ complexes are gaining increasing recent interest. In this work, we report on the synthesis, characterization $\left({ }^{1} \mathrm{H}\right.$ - and ${ }^{13} \mathrm{C}-\mathrm{NMR}$, FT-IR) and cytotoxicity studies of two new half-sandwich organometallic $\mathrm{Ru}(\mathrm{II})$ complexes of the general formula $\left[\mathrm{Ru}\left(\eta^{6}\right.\right.$-arene $\left.)(\mathrm{XY}) \mathrm{Cl}\right]\left(\mathrm{PF}_{6}\right)$ where arene $=$ benzene or toluene and $\mathrm{XY}=$ bidentates: dipyrido[3,2-a:2',3'-c]phenazine (dppz) or 2-(9-anthryl)-1H-imidazo[4,5-f][1,10]phenanthroline (aip), which are bound to $\mathrm{Ru}(\mathrm{II})$ via two phenanthroline-N atoms in a characteristic "piano-stool" configuration of $\mathrm{Ru}(\mathrm{II})$-arene 
complexes - as confirmed by vibrational and NMR spectra. In addition, cytotoxic studies were performed for similar half-sandwich organometallic $\left[\mathrm{Ru}\left(\eta^{6}-\mathrm{p}\right.\right.$-cymene $\left.)\left(\mathrm{Me}_{2} \mathrm{dppz}\right) \mathrm{Cl}\right] \mathrm{PF}_{6} \mathrm{complex}$ $\left(\mathrm{Me}_{2} \mathrm{dppz}=11,12\right.$-dimethyl-dipyrido[3,2-a:2',3'-c]phenazine). This study is complemented with elaborate modeling with density functional theory (DFT) calculations, which provided insight into reactive sites of $\mathrm{Ru}(\mathrm{II})$ structures, further detailed by Molecular Docking on the B-DNA dodecamer, which identified binding sites and affinities: most pronounced for the $\left[\mathrm{Ru}\left(\eta^{6}\right.\right.$-benzene)(aip)Cl] $\left(\mathrm{PF}_{6}\right)$ in both $\mathrm{A}-\mathrm{T}$ and $\mathrm{G}-\mathrm{C}$ regions of the DNA minor groove. Cytotoxic activity was probed versus tumor cell lines B16, C6 and U251 (B16 mouse melanoma, C6 rat glioma, U251 human glioblastoma) and non-tumor cell line HACAT (HACAT normal human keratinocytes).

Keywords: Ruthenium complexes; DNA Docking; Cytotoxicity studies; DFT Calculations; Intercalation

\section{Introduction}

The class of platinum compounds comprising cisplatin, carboplatin and oxaliplatin are the most widely known metal-based anticancer drugs [1]. Although cisplatin and its derivatives have had significant success in treatment of a vast majority of tumors, they are also toxic for non-cancer cells, have a limited range of activity, reduction of efficacy caused by drug resistance, and significant side-effects [2]. Despite great efforts to develop other less toxic but equally effective platinum-based drugs, clinical trials often show that these complexes have similar disadvantages as those associated with cisplatin therapy [3]. Due to these limitations, research of new anticancer drugs is increasingly focused on complexes with other metals, among which ruthenium complexes have raised great attention. Various ruthenium complexes have been tested against a number of cancer cell lines [4], and the three $\mathrm{Ru}(\mathrm{III})$ complexes: NAMI-A $(\mathrm{ImH})[$ trans-Ru(Im)(DMSO)Cl $]$ ((Im = imidazole, DMSO = dimethylsulfoxide $)$ [5], KP1019 [trans-tetrachloro-bis-(1H-indazole)-ruthenate(III)] [6], and its more soluble sodium salt, NKP 1339 trans-[Ru(Ind) $\left.{ }_{2} \mathrm{Cl}_{4}\right](\mathrm{IndH})($ Ind = indazole) have entered clinical trials [7]. $\mathrm{Ru}(\mathrm{III})$ complexes are in general thermodynamically and kinetically less stable than $\mathrm{Ru}(\mathrm{II})$ complexes, while the nature of ligands and net charge has a significant impact on the kinetics of the hydration of $\mathrm{Ru}(\mathrm{II} / \mathrm{III})$ complexes [8, 9]. Also, based on the reachable $\mathrm{Ru}(\mathrm{II} / \mathrm{III})$ redox potential 
in vivo, the antitumor properties of the $\mathrm{Ru}(\mathrm{III})$ complexes are related to their reduced oxidation state, to $\mathrm{Ru}(\mathrm{II})$. Consequently, many $\mathrm{Ru}(\mathrm{II})$ complexes have attracted interest as promising anticancer agents and the $\mathrm{Ru}(\mathrm{II})$-polypyridyl compound, TLD-1433, recently entered phase IB clinical trials [9].

Recent research has focused on promising anticancer properties of organometallic ruthenium(II)-arene compounds of the type $\left[\left(\eta^{6}\right.\right.$-arene $\left.) \mathrm{Ru}(\mathrm{XY})(\mathrm{Z})\right]$, also referred to as "pianostool" structures, where XY is a bidentate chelating ligand and $\mathrm{Z}$ is a leaving group [10]. These half-sandwich complexes are very attractive due to diverse possibilities for derivatization at the arene moiety, introduction of two mono- or one bidentate ligand at the XY-site, as well as functionalization with numerous biologically active groups [11]. Furthermore, the hydrophobic arene ring facilitates admittance of $\mathrm{Ru}(\mathrm{II})$ complexes into cells and contributes to their stability [9]. A recent study of a series of $\mathrm{Ru}(\mathrm{II})$-arene Schiff-base (RAS) complexes has shown that the RAS complexes with more hydrophobic ligands have higher intercellular accumulation (1,3,5trimethylbenzene > benzene, methylbenzene) [9, 11]. Our previous report also indicated that $p$-cymene as arene ligand and the planar aromatic $\mathrm{Me}_{2} \mathrm{dppz}\left(\mathrm{Me}_{2} \mathrm{dppz}=11,12-\right.$ dimethyldipyrido[3,2-a:2',3'-c]phenazine) as XY ligand facilitate transport of the complex cation across the cell membrane which may contribute to DNA binding [12]. In addition, our cytotoxic activity studies revealed that the complex had a significantly higher cytotoxic activity and DNAbinding properties than cisplatin. Therefore, further studies of $\mathrm{Ru}(\mathrm{II})$-arene complexes with intercalating ligands such as dppz were pursued with the aim at increasing our understanding of promising anticancer reactivity. In this paper, we present the synthesis, characterization, and biological evaluation of two new "piano stool" ruthenium(II)-arene complexes, complemented with theoretical studies using density functional theory (DFT) and molecular docking methodology. Besides two similar complexes are studied by DFT and their cytotoxic activity was determined for comparison reasons.

\section{Experimental}

\subsection{Materials}

All chemicals were of reagent-grade quality or higher, were obtained from commercial suppliers and were used without purification. Solvents were used as received. $\mathrm{RuCl}_{3}$ was purchased from Acros Organics. 


\subsection{Instrumentation and methods}

${ }^{1} \mathrm{H}$ and ${ }^{13} \mathrm{C}$ NMR spectra were recorded in deuterated solvents on a Bruker Ultrashield Advance III spectrometer $500\left({ }^{1} \mathrm{H}: 500 \mathrm{MHz},{ }^{13} \mathrm{C}: 126 \mathrm{MHz}\right)$ at room temperature. The residual solvent peaks have been used as an internal reference. Infrared spectra were recorded on a Nicolet 6700 FT-IR spectrometer using the ATR technique. ESI mass spectra measurements of complexes were carried out on a MS system LTQ Orbitrap XL with heated ESI ionization in methanol solutions. UV-vis spectra were recorded on GBC Cintra 40 spectrophotometer.

\subsection{Synthesis}

The ligands 11,12-dimethyldipyrido[3,2-a:2',3'-c]phenazine (Me $2 \mathrm{dppz})$ and dipyrido[3,2-a:2',3'c]phenazine (dppz) were synthesized by condensation of 1,10-phenathroline-5,6-dione [13] with 4,5-dimethylbenzene-1,2-diamine or $o$-phenylenediamine according to a published procedure [14]. The ligand 2-(9-anthryl)-1H-imidazo[4,5-f][1,10]phenanthroline (aip) was prepared by condensation of the same dione with 9-anthraldehyde under conditions described in the literature [15]. The ruthenium dimers $\left[\left(\eta^{6}-p \text {-cymene }\right) \mathrm{RuCl}_{2}\right]_{2}, \quad\left[\left(\eta^{6} \text {-toluene }\right) \mathrm{RuCl}_{2}\right]_{2} \quad$ and $\left[\left(\eta^{6} \text {-benzene }\right) \mathrm{RuCl}_{2}\right]_{2}$ were prepared according to a published procedure [16]. Complex $\left[\mathrm{Ru}\left(\eta^{6}-\mathrm{p}-\right.\right.$ cymene) $\left.\left(\mathrm{Me}_{2} \mathrm{dppz}\right) \mathrm{Cl}\right]\left(\mathrm{PF}_{6}\right)(2)$ [12] was synthesized according to a published procedure.

$\left[\mathrm{Ru}\left(\eta^{6}\right.\right.$-toluene $\left.)(\mathrm{dppz}) \mathrm{Cl}\right]\left(\mathrm{PF}_{6}\right)(\mathbf{1})$

To a suspension of $\left[\left(\eta^{6} \text {-toluene }\right) \mathrm{RuCl}_{2}\right]_{2}(167 \mathrm{mg}, 0.316 \mathrm{mmol})$ in $15 \mathrm{~mL}$ of methanol a solution of dppz (179 mg, $0.632 \mathrm{mmol}$ ) in $15 \mathrm{~mL}$ of dichloromethane was added dropwise. The reaction mixture was stirred for $6 \mathrm{~h}$ at room temperature and filtered. Then $\mathrm{NH}_{4} \mathrm{PF}_{6}$ (155 mg, $0.948 \mathrm{mmol}$ ) was added to the solution that was left stirring overnight. The pale yellow precipitate was filtered off, washed with cold $\mathrm{MeOH}$ and $\mathrm{Et}_{2} \mathrm{O}$ and dried in vacuo. Yield: $256 \mathrm{mg}, 62 \% .{ }^{1} \mathrm{H}$ NMR (500 MHz, DMSO) $\delta(\mathrm{ppm}): 10.03$ (d, $\left.J=4.2 \mathrm{~Hz}, 2 \mathrm{H}\right), 9.51(\mathrm{~d}, J=$ $7.7 \mathrm{~Hz}, 2 \mathrm{H}), 8.25(\mathrm{dd}, J=18.6,12.5 \mathrm{~Hz}, 4 \mathrm{H}), 7.98(\mathrm{~s}, 2 \mathrm{H}), 6.51(\mathrm{~s}, 2 \mathrm{H}), 6.14(\mathrm{~d}, J=5.2 \mathrm{~Hz}, 2 \mathrm{H})$, 5.96 (s, 1H), 2.34 (s, 3H). ${ }^{13} \mathrm{C}$ NMR (126 MHz, DMSO) $\delta(\mathrm{ppm}): 157.49,147.97,141.64,138.74$, $135.15,132.40,129.20,129.10,127.47,105.84,90.13,83.00,80.26,18.89$. IR (ATR, $\left.\mathrm{cm}^{-1}\right)$ : 3097 (w), 2988 (w), 2942 (w), 1497 (w), 1442 (w), 1411 (w), 1356 (w), 833 (s), 731 (w), 556 (w). UV-vis (nm, DMSO): 278, 318, 364, 382. ESI-MS (in DMSO, m/z): $511.1\left(\left[\mathrm{M}-\mathrm{PF}_{6}\right]^{+}\right)$. 
$\left[\mathrm{Ru}\left(\eta^{6}-p\right.\right.$-benzene $\left.)(\mathrm{aip}) \mathrm{Cl}\right]\left(\mathrm{PF}_{6}\right)(\mathbf{3})$

To a suspension of $\left[\left(\eta^{6} \text {-benzene }\right) \mathrm{RuCl}_{2}\right]_{2}(18 \mathrm{mg}, 0.036 \mathrm{mmol})$ in $5 \mathrm{~mL}$ of methanol was added dropwise a solution of aip $(27 \mathrm{mg}, 0.068 \mathrm{mmol})$ in $5 \mathrm{~mL}$ of dichloromethane. The reaction mixture was stirred for $5 \mathrm{~h}$ at room temperature and filtered. Then $\mathrm{NH}_{4} \mathrm{PF}_{6}(18 \mathrm{mg}, 0.110 \mathrm{mmol})$ was added to the solution and left overnight with stirring. The pale yellow precipitate was filtered, washed with cold $\mathrm{MeOH}$ and $\mathrm{Et}_{2} \mathrm{O}$ and dried in vacuo. Yield: $50 \mathrm{mg}, 97 \%$. ${ }^{1} \mathrm{H} \mathrm{NMR}$ (200 MHz, DMSO) $\delta(\mathrm{ppm}): 14.82$ (s, 1H), 10.02 (dd, J = 5.3, $1.0 \mathrm{~Hz}, 2 \mathrm{H}), 9.18$ (s, 2H), 8.96 (s, $1 \mathrm{H}), 8.24(\mathrm{~m}, 4 \mathrm{H}), 7.76(\mathrm{~d}, J=8.5 \mathrm{~Hz}, 2 \mathrm{H}), 7.58(\mathrm{dt}, J=14.9,6.2 \mathrm{~Hz}, 5 \mathrm{H}), 6.38(\mathrm{~d}, J=7.4 \mathrm{~Hz}$, $6 \mathrm{H}) .{ }^{13} \mathrm{C}$ NMR (50 MHz, DMSO) $\delta(\mathrm{ppm}): 153.92,150.66,143.31,132.44,130.82,130.64$, 129.61, 128.64, 127.31, 126.39, 125.83, 125.49, 124.40, 104.02, 86.23. IR (ATR, cm ${ }^{-1}$ ): 3640(w), 3060 (m), 2970 (m), 2930 (m), 1607 (w), 1544 (w), 1507 (w), 1447 (w), 1413 (w), 1365 (w), 839 (s), 742 (m), 556 (w). UV-vis (nm, DMSO): 254, 294, 342, 360, 378. ESI-MS (in DMSO, m/z): $611.1\left(\left[\mathrm{M}-\mathrm{PF}_{6}\right]^{+}\right)$.

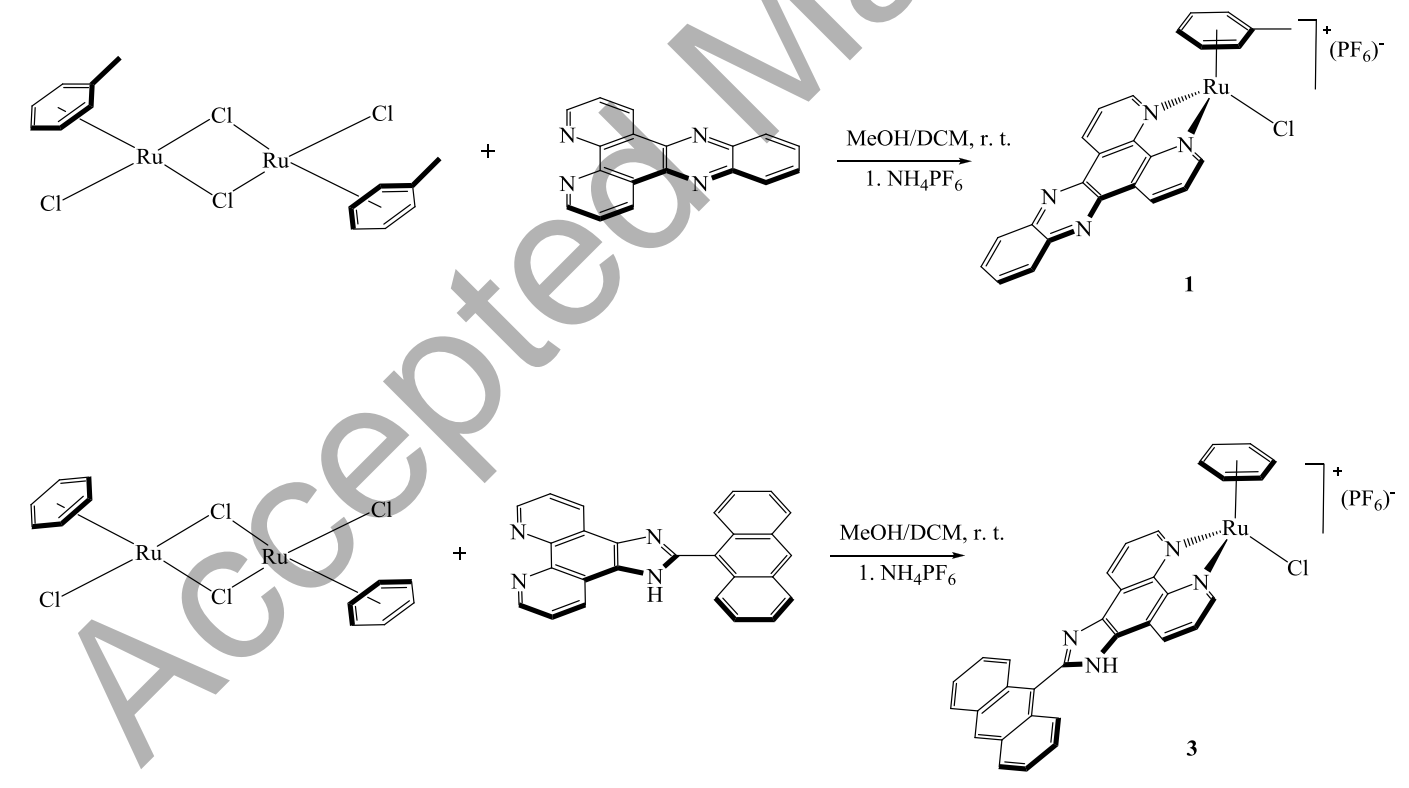

Scheme 1. Synthesis of $\mathbf{1}$ and 3. 


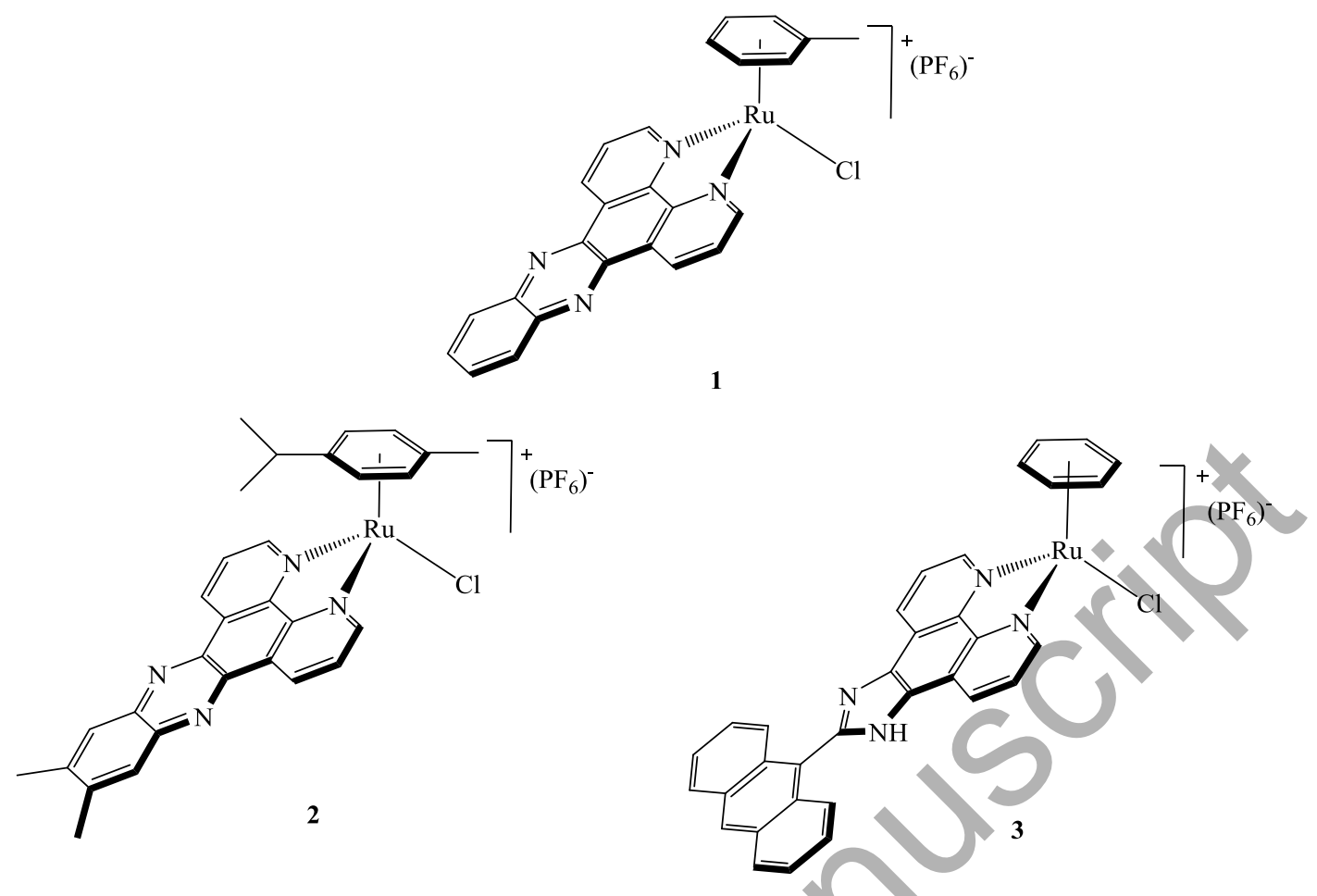

Scheme 2. Structure of the complexes.

\subsection{Computational details}

All complexes were optimized at the DFT level with the hybrid wB97XD functional, a LANL2DZ effective core potential for Ru ion, and a 6-311G(d) basis set for all other atoms, without symmetry constraints. The same level was used for the frequency calculations and confirmation that optimized geometry has only real frequencies. The gas phase structures of $\mathbf{1}$ and 3 were re-optimized in DMSO, simulated by the universal solvation model (SMD) [17]. Calculated electronic transitions were carried out within the time dependent density functional theory (TD-DFT) approach, using the same functional, the basis sets and the solvent.

The quantum chemical calculations were done with Gaussian09 software [18]. The condensed Fukui function is calculated from eqns. 1-3, where $q_{N}, q_{N-1}$ and $q_{N+1}$ are the partial charge of the atom $A$ in neutral, anionic and cationic forms, respectively. 
nucleophilic attack:

$$
f^{+}(r)=\rho_{N+1}(r)-\rho_{N}(r)
$$

electrophilic attack:

$$
f^{-}(r)=\rho_{N}(r)-\rho_{N-1}(r)
$$

radical attack:

$$
f^{0}(r)=\frac{f^{+}(r)+f^{-}(r)}{2}
$$

The condensed dual descriptor is calculated from eqn. 4.

$$
\Delta f(r)=f^{+}(r)-f^{-}(r)
$$

The NPA [19] and Mulliken [20] partial atomic charges were used to calculate values of condensed Fukui function and condensed dual descriptor at the ground state geometry in vacuum. Calculations were carried on the PARADOX supercomputing facility [21].

\subsection{Molecular docking}

Docking of flexible ligands (Ru(II) complexes) against rigid receptor molecule (B-DNA) were performed using the AutoDock suite of programs (AutoDock 4.2) [22].

The DFT optimized structures of 1-3 at wB97XD/6-311G(d)/LANL2DZ levels of theory were used. The crystal data of the B-DNA dodecamer d(CGCGAATTCGCG)2 (PDB ID:1BNA) were downloaded from the Protein Data Bank. The water molecules were removed from the 1BNA and Gasteiger charges were added to the complexes by Autodock 4.2 Tools (ADT) before performing docking calculations. The binding site was centered on the DNA molecule and a grid box was created so that it involved the entire DNA molecule. The most stable docked ligand conformations were found by performing the rigid docking protocol and 10 runs of the Lamarckian genetic algorithm. 


\subsection{Cell culture}

Mouse melanoma (B16), rat glioma (C6), human glioblastoma (U251) and human keratinocytes (HACAT) were obtained from European Collection of Cell Cultures ECACC. For experiments, cells were grown in RPMI-1640 medium and high glucose DMEM medium supplemented with 5\% (RPMI-1640) and 10\% FCS (DMEM), glutamate and antibiotics (culture medium) at $37{ }^{\circ} \mathrm{C}$ in a humidified atmosphere with $5 \% \mathrm{CO}_{2}$. Cells were prepared using trypsinization procedure with trypsin/EDTA and seeded in Perti dishes $\left(10 \mathrm{~cm}, 2.5 \times 10^{6}\right.$ cells $)$ and flat-bottom 96-well tissue culture plates $\left(15 \times 10^{4}\right.$ cells/well) for viability assays (Sarstedt, Numbrecht, Germany).

For the biological examination, 1-3 were dissolved in DMSO, as a $100 \mathrm{mM}$ stock solution. This solution was further dissolved in appropriate cell culture media, depending on cell culture used in experiment. The DMSO concentration in maximal concentration of extract (1 $\mathrm{mM}$ ) prepared for cell treatment was $1 \%$. Cells were treated in serial solutions (from $1 \mathrm{mM}$ to $0.015 \mathrm{mM}$, prepared in culture medium) and after $24 \mathrm{~h}$ cell viability was determined using MTT and Crystal violet methods.

\subsection{Trypan blue exclusion assay}

Trypan blue exclusion assay was used to determine the number of viable cells present in a cell suspension. Viable cells with intact membranes exclude trypan blue dye and appear with clear cytoplasm, whereas non-viable cells do not, and cytoplasm remains blue. Cell suspension $(20 \mu \mathrm{L})$ was mixed with $180 \mu \mathrm{L}$ of filtered TB solution $(0.4 \%)$ and cell number was determined using a hemocytometer.

\subsection{Cytotoxicity studies}

Cell viability was measured using assays for adherent cell lines, MTT and Crystal violet (CV). MTT assay is based on the ability of metabolically viable cells to bind and reduce MTT to formazan crystals in mitochondria. Cells were incubated with MTT $(0.5 \mathrm{mg} / \mathrm{mL})$ for $1.5 \mathrm{~h}$ after which MTT was removed and formazan crystals were dissolved with DMSO. The absorbances were measured by an automated microplate reader at $570 \mathrm{~nm}$, and the results were presented as $\%$ of viability relative to untreated control cultures (viability $100 \%$ ).

For CV assay, after $24 \mathrm{~h}$ treatment, cell cultures were washed with PBS, fixed with methanol and incubated for 10 min with $1 \%$ crystal violet dye. After incubation, plates were 
washed with water and CV bound to the proteins was dissolved in $33 \%$ acetic acid. The absorbance was measured in an automated microplate reader at $570 \mathrm{~nm}$ (Sunrise, TECAN, UK). The absorbance values are correlated to the number of viable cells. Results were presented as $\%$ of viability relative to untreated control cultures (viability 100\%).

Viability assays were used to calculate $\mathrm{IC}_{50}$ value, which represents the concentration that leads to decrease in cell viability for $50 \%$ comparing to untreated cells. $\mathrm{IC}_{50}$ value was calculated using GraphPad Prism program.

\section{Results and discussion}

\subsection{Characterization of the complexes}

Complexes were synthesized following the synthetic routes described in scheme 1 and published procedures. The resulting complexes were soluble in DMSO. All complexes were characterized by ${ }^{1} \mathrm{H}$ and ${ }^{13} \mathrm{C}$ NMR and IR (figures S1-S6). ${ }^{1} \mathrm{H}$ and ${ }^{13} \mathrm{C}$ NMR spectra of the complexes suggest "piano-stool" geometry. As determined by the integrals of the ${ }^{1} \mathrm{H}$ NMR spectra, the arene to dppz/Me $\mathrm{Mepz}_{2}$ aip ratio was $1: 1$.

\subsection{Stability of the complexes in DMSO and $\mathrm{DMSO} / \mathrm{D}_{2} \mathrm{O}$ solution}

In order to check whether the complexes are stable towards ligand exchange in DMSO solutions [23] we have followed their ${ }^{1} \mathrm{H}-\mathrm{NMR}$ spectra in $\mathrm{DMSO}-\mathrm{d}_{6}$ and did not find any noticeable change over $48 \mathrm{~h}$ (figures S7 and S8). Therefore, DMSO solutions were used as stock solutions for cytotoxicity experiments. In addition, the stability of complexes in $\mathrm{DMSO} / \mathrm{D}_{2} \mathrm{O}$ mixture was

also followed by ${ }^{1} \mathrm{H}-\mathrm{NMR}$ spectroscopy (figures S9 and S10). Also, this experiment showed no change in spectra.

\subsection{Geometry optimization}

The initial geometry of Ru complex, labelled as 'Model System' (MS), was taken from the single crystal X-ray data [24] and subjected to optimization at the DFT level with several functionals and basis sets (table 1). The performance of three functionals without dispersion (B3LYP [25, 26], CAM-B3LYP [27] and TPSS [28]) and two which include dispersion (B97D [29] and wB97XD [30]), have been tested in reproducing molecular structures. Different basis sets were applied for the ligands: 6-31G(d) [31, 32], 6-31G(d,p) [33], 6-31G++(d) and 6-31G+(d) [34, 35], 
6-311G(d) [36, 37], as well as for the metal ion: Lanl2dz with effective core potentials (EPC) [38] and SDD EPC [39].

Within the B3LYP functional, additional p-type polarization functions on the atoms of ligands have no significant effect on the reproduction of structural parameters. Application of the 6-31G++(d) basis set that adds diffuse functions on each of the ligands atoms leads to a significant increase of $\mathrm{Ru}$-centroid and $\mathrm{Ru}-\mathrm{Cl}$ distance. We have found that the use of SDD EPC basis set for metal ion yields slightly better reproduction of experimental structural parameters. The metal-ligand distances obtained using CAM-B3LYP, TPSSTPSS, B97D and wB97XD functionals are better in comparison to B3LYP, whereas the combination wB97XD/6-311G(d)/Lanl2dz does give the closest agreement with experimental values (table 1). The results are consistent with conclusions of extensive theoretical studies of similar $\mathrm{Ru}(\mathrm{II})$ compounds [40].

According to these results (table 1), the combination of functional and basis sets wB97XD/6-311G(d)/Lanl2dz appears to be the most appropriate for reproducing the X-ray structure of complex MS. Therefore, it was adopted for optimization of all investigated Ru(II) complexes. Their optimized molecular structures are represented in figure 1, while table 2 lists a comparison of important bond distances and angles. As can be noticed, there are no major changes in bond and angle parameters upon varying the diimine and arene co-ligands.

In all monocationic complexes the dppz ligand or its derivatives is coordinated to $\mathrm{Ru}(\mathrm{II})$ ion through the nitrogen atoms in a bidentate manner, forming a five-membered metallacycle. The Ru(II) complexes have distorted pseudo-octahedral geometry which consists of two nitrogen atoms and the chloride atom, which refer to the legs of the stool, while the $\eta^{6}$-arene ring forms the seat of the "three-legged piano stool" structure. Such piano-stool geometry is already observed and reported in many half-sandwich ruthenium(II)-arene complexes [41]. All bond lengths calculated by the present DFT method are in good agreement with available experimental data. Also, calculated bond lengths fall within the reported values for similar half-sandwich $\mathrm{Ru}(\mathrm{II})$ complexes, which ranged from $2.076 \AA$ to $2.112 \AA$ for $\mathrm{Ru}-\mathrm{N}$, from $2.380 \AA$ to $2.415 \AA$ for $\mathrm{Ru}-\mathrm{Cl}$, and from $2.150 \AA$ to $2.211 \AA$ for $\mathrm{Ru}-\mathrm{C}[8,42]$. The bite angle of N-Ru-N is lower than the bond angles involving chloride ion $\mathrm{N}-\mathrm{Ru}-\mathrm{Cl}$ as experimentally already observed [42a]. These angular values near $90^{\circ}$ are commonly quoted as evidence of piano stool structure [42b]. Experimental spectra of $\mathbf{1}$ and $\mathbf{3}$ recorded in DMSO solution were compared with the calculated 
spin-allowed electronic transitions (figures S11 and S12). The nature of the singlet-singlet transitions responsible for the absorption bands was assigned using TD-DFT calculations.

The absorption spectra of the newly synthesized ruthenium(II) complexes (1 and $\mathbf{3}$ ) exhibited two sets of the absorption bands. The very intense bands in the UV region of 220$300 \mathrm{~nm}$ could be assigned to the intraligand $\pi-\pi^{*}$ transitions. Also, $\mathbf{1}$ and $\mathbf{3}$ showed weak absorption bands in the range of 300-400 nm which correspond to MLCT (metal to ligand charge transfer) transitions [41a, 43]. Composition of MOs (figures S11 and S12) involved in major calculated transitions confirmed such assignation of the absorption bands.

\subsection{Reactivity analysis}

An analysis of the frontier molecular orbitals involved consideration of the HOMO orbitals as nucleophilic or electron donating and the LUMO orbitals as electrophilic and electron accepting. Figure 2 shows graphic representations of the calculated HOMO and LUMO orbitals for investigated $\mathrm{Ru}(\mathrm{II})$ complexes. The composition of MOs are very similar for MS, 1 and 2 . The LUMO orbitals of these complexes have a contribution mainly from the dppz ligand or its derivatives. The main contribution to the HOMO orbitals of these complexes derives from the chloride atom, metal center and $\eta^{6}$-arene ring. The situation is quite different for $\mathbf{3}$. The dppz ligand, the chloride atom and metal center have participation in the LUMO orbitals, while anthracene group almost entirely contribute to HOMO orbitals. These differences of MOs composition may cause different reactivity of investigated complexes.

Based on Parr and Yang [44] theory we studied molecular reactivity of Ru(II) complexes by calculating Fukui functions. The reactivity of sites in a chemical species is best viewed through the Fukui functions: $f^{+}$for the nucleophilic, $f^{-}$for the electrophilic, $f^{0}$ for the radical attack and dual descriptor $\Delta f$, considering the NPA and Mulliken charges (see Computational methodology). Unlike Fukui function, $\Delta f$ reveals both types of reactive sites. If $\Delta f>0$, then the site is favorable for a nucleophilic attack, whereas if $\Delta f<0$, then the site is favorable for an electrophilic attack.

As shown in table 3, $\mathrm{Ru}$ and $\mathrm{Cl}$ are the only reactive centers for $\mathbf{M S}$ and these atoms are favorable for an electrophilic and radical attack. The most reactive sites of the molecule upon nucleophilic attack are $\mathrm{C} 9$ and $\mathrm{C} 22$ atoms of dppz ligand and $\mathrm{Cl}$ atom for radical attack. In the 
case of $\mathbf{1}$, the asymmetric substitution of benzene ring leads to the appearance of new reactive centers for nucleophilic attack (C21, C23). Complex 2 has the reactive sites for nucleophilic attack at C9 and C24, due to para substituted benzene ring. Additional methyl group of dppz ligand may be responsible for the new reactive centers, C14 and C19, which are the most favorable for an electrophilic and radical attack. Also, $\mathbf{3}$ has similar reactive sites of aip ligand upon nucleophilic attack (C9, C10, C30, C31), but the most favorable centers for an electrophilic attack are located on the anthracene group $(\mathrm{C} 14, \mathrm{C} 21)$. The main difference in the values of the Fukui functions calculated using the NPA and Mulliken charges can be noted for the metal ion, but the values for other atoms have the same trends.

\subsection{Molecular docking with DNA}

In order to explore the most feasible binding sites, interaction modes, and binding affinities docking studies have been performed on the $\mathrm{Ru}$ (II) complexes (1-3) with B-DNA (PDB ID: 1BNA). The docked model (figure 3 ) revealed that $\mathbf{1}$ and $\mathbf{2}$ were tailored tightly into the curved contour of the targeted DNA minor groove within A-T rich region, in such a way that planar part of the aromatic rings made favorable electrostatic ( $\pi$-anion) and hydrophobic ( $\pi$-sigma) contacts with the DNA functional groups. Complex 3 interacts with DNA through electrostatic ( $\pi$-anion) and hydrophobic ( $\pi$-sigma) interactions at the minor groove with an affinity to both A-T and G-C region.

The resulting binding energies of docked structures were $-8.50,-8.52$ and $-10.09 \mathrm{kcal} / \mathrm{mol}$ for 1-3, respectively, indicating the higher binding affinity between DNA and $\mathbf{3}$ as compared to $\mathbf{1}$ and 2. In addition, the results indicate that there are certain hydrogen-bonding interaction between 1-2 and DNA. The length of these hydrogen bonds are $2.201 \AA$ (H (DA-6)/N3 (ligand) for 1 and 2.266 $\AA$ (N (DA-6)/H3 (N4)) for 2.

\subsection{Cytotoxic activity of the complexes}

The cytotoxicity of the complexes was studied in three cancer cell lines B16, C6, U251 and normal human ketatinocytes cell line, HACAT. As shown in table 4, cell lines show different sensitivity on the treatment. 
Regarding the treatment with 1, HACAT cell line was sensitive $\left(\mathrm{IC}_{50}=0.06 \mathrm{mM}\right)$ while among tumor cell lines, only in B16 cell viability was decreased below 50\%, which is a necessary condition for the calculation of $\mathrm{IC}_{50}$ values $\left(\mathrm{IC}_{50}=0.5 \mathrm{mM}\right)$.

Treatment with 2 exerted cytotoxic effect only on tumor cell lines where U251 and C6 were more sensitive $\left(\mathrm{IC}_{50}\right.$ for both cell lines was $\left.0.125 \mathrm{mM}\right)$ in comparison to $\mathrm{B} 16\left(\mathrm{IC}_{50}=1 \mathrm{mM}\right.$, which is the highest concentration used for treatment).

Complex 3 exerted cytotoxic effect only on HACAT cell line $\left(\mathrm{IC}_{50}=0.83 \mathrm{mM}\right)$, while all tumor cell lines remained unsensitive $\left(\mathrm{IC}_{50}>1 \mathrm{mM}\right)$.

\section{Conclusion}

In this study, half-sandwich $\mathrm{Ru}(\mathrm{II})$-arene complexes have been synthesized, characterized and their geometry has been optimized. Cytotoxic studies on three human tumor cell lines (B16, C6 and U251) and one non-tumor in vitro cell model (HACAT) revealed moderate cytotoxic activity. Molecular docking experiments revealed intercalating potential to nuclear DNA. Organic agents that strongly bind DNA via intercalation are extremely successful anticancer agents. However, as shown in this study, this strong DNA intercalation is not a crucial interaction responsible for cytotoxic activity. Further structure-activity study in our laboratories will be directed toward obtaining complexes with a higher selectivity.

\section{Acknowledgement}

Authors acknowledge support of the Serbian Ministry of Education and Science (Grant No. 172035). S.G. and R.D. acknowledge support of the COST CMST-Action CM1405 Molecules in Motion (MOLIM). 


\section{References}

[1] (a) G. Chu. J. Biol. Chem., 269, 787 (1994). (b) E.R. Jamieson, S.J. Lippard. Chem. Rev., 99, 2467 (1999). (c) T. Boulikas, M. Vougiouka. Oncol. Rep., 10, 1663 (2003). (d) V. Cepeda, M.A. Fuertes, J. Castilla, C. Alonso, C. Quevedo, J.M. Pérez. Anti-(f) Cancer Agents Med. Chem., 7, 3 (2007). (e) L. Kelland. Nat. Rev. Cancer, 7, 573 (2007). (f) F. Arnesano, G. Natile. Coord. Chem. Rev., 253, 2070 (2009).

[2] (a) A.-M. Florea, D. Büsselberg. Cancers, 3, 1351 (2011). (b) L. Galluzzi, L. Senovilla, I. Vitale, J. Michels, I. Martins, O. Kepp, M. Castedo, G. Kroemer. Oncogene, 31, 1869 (2012). (c) Y.-R. Zheng, K. Suntharalingam, T.C. Johnstone, H. Yoo, W. Lin, J.G. Brooks, S.J. Lippard. J. Am. Chem. Soc., 136, 8790 (2014). (d) K. Suntharalingam, Y. Song, S.J. Lippard. Chem. Commun., 50, 2465 (2014).

[3] (a) S. Dhar, F.X. Gu, R. Langer, O.C. Farokhzad, S.J. Lippard. Proc. Natl. Acad. Sci. U.S.A., 105, 17356 (2008). (b) S.H. van Rijt, P.J. Sadler. Drug Discov. Today, 14, 1089 (2009).

[4] (a) C.X. Zhang, S.J. Lippard. Curr. Opin. Chem. Biol., 7, 481 (2003). (b) I. Kostova. Curr. Med. Chem., 13, 1085 (2006). (c) A. Levina, A. Mitra, P.A. Lay. Metallomics, 1, 458 (2009). (d) G.S. Smith, B. Therrien. Dalton Trans., 40, 10793 (2011). (e) P. Liu, J. Jia, Y. Zhao, K. Wang. Mini-Rev. Med. Chem., 16, 272 (2015). (f) J. Furrer, G. SüssFink. Coord. Chem. Rev., 309, 36 (2016).

[5] (a) A. Bergamo, S. Zorzet, B. Gava, A. Sorc, E. Alessio, E. Iengo, G. Sava. Anti-Cancer Drugs, 11, 665 (2000). (b) M. Bacac, M. Vadori, G. Sava, S. Pacor. Cancer Immunol. Immunother., 53, 1101 (2004). (c) A. Bergamo, B. Gava, E. Alessio, G. Mestroni, B. Serli, M. Cocchietto, S. Zorzet, G. Sava. Int. J. Oncol., 21, 1331 (2002). (d) M. Debidda, B. Sanna, A. Cossu, A.M. Posadino, B. Tadolini, C. Ventura, G. Pintus. Int. J. Oncol., 23, 477 (2003).

[6] (a) C.G. Hartinger, S. Zorbas-Seifried, M.A. Jakupec, B. Kynast, H. Zorbas, B.K. Keppler. J. Inorg. Biochem., 100, 891 (2006). (b) C.G. Hartinger, M.A. Jakupec, S. Zorbas-Seifried, M. Groessl, A. Egger, W. Berger, H. Zorbas, P.J. Dyson, B.K. Keppler. Chem. Biodiversity, 5, 2140 (2008). 
[7] A.K. Bytzek, G. Koellensperger, B.K. Keppler, C.G. Hartinger. J. Inorg. Biochem., 160, 250 (2016).

[8] M. Abid, F. Shamsi, A. Azam. Mini-Rev. Med. Chem., 10, 772 (2016).

[9] L. Zeng, P. Gupta, Y. Chen, E. Wang, L. Ji, H. Chao, Z.-S. Chen. Chem. Soc. Rev., 46, 5771 (2017).

[10] W.M. Motswainyana, P.A. Ajibade. Adv. Chem., 2015, 21 (2015).

[11] M.J. Chow, M.V. Babak, D.Y.Q. Wong, G. Pastorin, C. Gaiddon, W.H. Ang. Mol. Pharmaceutics, 13, 2543 (2016).

[12] S. Nikolić, L. Rangasamy, N. Gligorijević, S. Aranđelović, S. Radulović, G. Gasser, S. Grgurić-Šipka. J. Inorg. Biochem., 160, 156 (2016).

[13] R.D. Gillard, R.E.E. Hill, R. Maskill. J. Chem. Soc. A, 1447 (1970).

[14] (a) C.M. Dupureur, J.K. Barton. Inorg. Chem., 36, 33 (1997). (b) J.E. Dickeson, L.A. Summers. Aust. J. Chem., 23, 1023 (1970).

[15] P. Nagababu, M. Shilpa, B. Mustafa, P. Ramjee, S. Satyanarayana, I. IvanovićBurmazović. Inorg. React. Mech., 6, 301 (2008).

[16] S.B. Jensen, S.J. Rodger, M.D. Spicer.J. Organomet. Chem., 556, 151 (1998).

[17] A.V. Marenich, C.J. Cramer, D.G. Truhlar. J. Phys. Chem. B, 113, 6378 (2009).

[18] Gaussian 09 (Revision D.01), Gaussian, Inc., Wallingford, CT (2009).

[19] A.E. Reed, L.A. Curtiss, F.A.J. Weinhold. Chem. Rev., 88, 899 (1988).

[20] R.S. Mulliken. J. Chem. Phys., 23, 1833 (1955).

[21] PARADOX IV cluster at the Scientific Computing Laboratory of the Institute of Physics Belgrade, supported in part by the Serbian Ministry of Education and Science under project No. ON171017.

[22] G.M. Morris, R. Huey, W. Lindstrom, M.F. Sanner, R.K. Belew, D.S. Goodsell, A.J. Olson. J. Comput. Chem., 16, 2785 (2009).

[23] M. Patra, T. Joshi, V. Pierroz, K. Ingram, M. Kaiser, S. Ferrari, B. Spingler, J. Keiser, G. Gasser. Chem. Eur. J., 19, 14768 (2013).

[24] A. Frodl, D. Herebian, W.S. Sheldrick. J. Chem. Soc., Dalton Trans., 0, 3664 (2002).

[25] A.D. Becke. J. Chem. Phys., 98, 5648 (1993).

[26] C. Lee, W. Yang, R.G. Parr. Phys. Rev., B: Condens. Mater. Phys., 37, 785 (1988).

[27] T. Yanai, D. Tew, N. Handy. Chem. Phys. Lett., 393, 51 (2004). 
[28] J.M. Tao, J.P. Perdew, V.N. Staroverov, G.E. Scuseria. Phys. Rev. Lett., 91, 146401 (2003).

[29] S. Grimme. J. Comp. Chem., 27, 1787 (2006).

[30] J.-D. Chai, M. Head-Gordon. Phys. Chem. Chem. Phys., 10, 6615 (2008).

[31] P.C. Hariharan, J.A. Pople. Theoret. Chim, Acta, 28, 213 (1973).

[32] M.M. Francl, W.J. Petro, W.J. Hehre, J.S. Binkley, M.S. Gordon, D.J. DeFrees, J.A. Pople. J. Chem. Phys., 77, 3654 (1982).

[33] W.J. Hehre, R. Ditchfield, J.A. Pople. J. Chem. Phys., 56, 2257 (1972).

[34] (a) T. Clark, J. Chandrasekhar, G.W. Spitznagel, P. von Ragué Schleyer. J. Comp. Chem., 4, 294 (1983). (b) R. Krishnam, J.S. Binkley, R. Seeger, J.A. Pople. J. Chem. Phys., 72, 650 (1980).

[35] P.M.W. Gill, B.G. Johnson, J.A. Pople, M.J. Frisch. Chem. Phys. Lett., 197, 499 (1992).

[36] R. Krishnan, J.S. Binkley, R. Seeger, J.A. Pople. J. Chem. Phys., 72, 650 (1980).

[37] A.D. McLean, G.S. Chandler. J. Chem. Phys., 72, 5639 (1980).

[38] (a) P.J. Hay, W.R. Wadt. J. Chem. Phys., 82, 270 (1985). (b) P.J. Hay, W.R. Wadt. J. Chem. Phys., 82, 284 (1985). (c) P.J. Hay, W.R. Wadt. J. Chem. Phys., 82, 299 (1985).

[39] D. Andrae, U. Haussermann, M. Dolg, H. Stoll, H. Preuss. Theor. Chim. Acta, 77, 123 (1990).

[40] Y. Minenkov, Å. Singstad, G. Occhipinti, V.R. Jensen. Dalton Trans., 41, 5526 (2012).

[41] (a) J.M. Gichumbi, H.B. Friedrich, B. Omondi. J. Organomet. Chem., 808, 87 (2016).

(b) M. Kasim, M. Subarkhan, R. Ramesh, Y. Liu. New J. Chem., 40, 9813 (2016). (c) F. Marchetti, C. Pettinari, R. Pettinari, A. Cerquetella, C. Di Nicola, A. Macchioni, D. Zuccaccia, M. Monari, F. Piccinelli. Inorg. Chem., 47, 11593 (2008). (d) D. Pandiarajan, R. Ramesh. J. Organomet. Chem., 723, 26 (2013).

[42] (a) M. Ganeshpandian, M. Palaniandavar, A. Muruganantham, S.K. Ghosh, A. Riyasdeen, M.A. Akbarsha. Appl. Organomet. Chem., 32, e4154 (2017). (b) Q. Wu, K. Zheng, S. Liao, Y. Ding, Y. Li, W. Mei. Organometallics, 35, 317 (2016). (c) J.G. Małecki, M. Jaworska, R. Kruszynski. J. Organomet. Chem., 692, 2903 (2007). (d) J. Canivet, L. Karmazin-Brelot, G. Süss-Fink. J. Organomet. Chem., 690, 3202 (2005).

[43] A. Terenzi, G. Barone, A. Silvestri, A.M. Giuliani, A. Ruggirello, V.T. Liveri. J. Inorg. Biochem., 103, 1 (2009). 
[44] (a) R.G. Parr, W. Yang. J. Am. Chem. Soc., 106, 4049 (1984). (b) W. Yang, R.G. Parr, R. Pucci. J. Chem. Phys., 81, 2862 (1984). (c) W. Yang, R.G. Parr. Proc. Nat. Acad. Sci. USA, 82, 6723 (1985). (d) W. Yang, W.J. Mortier. J. Am. Chem. Soc., 108, 5708 (1986).

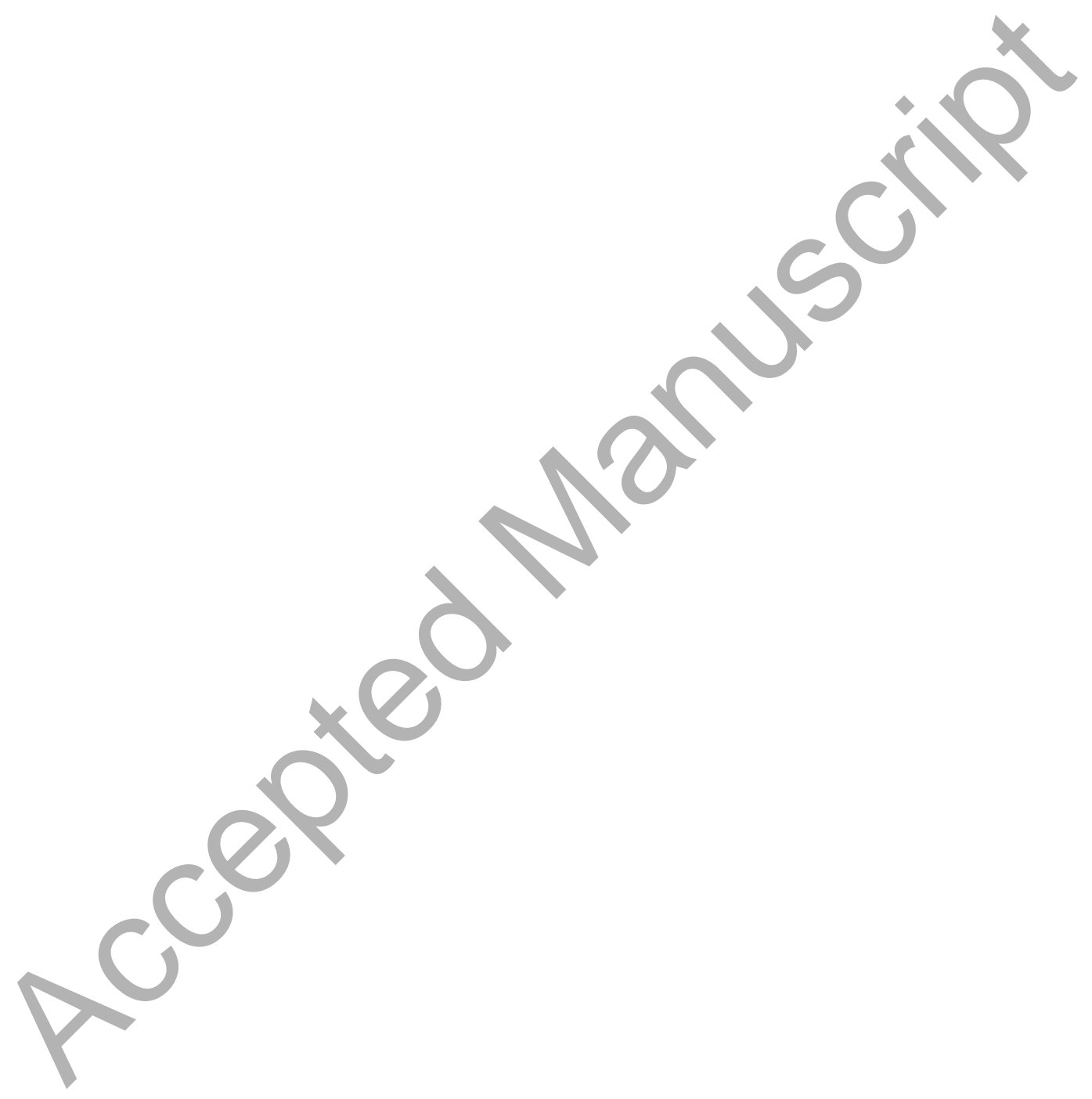


Figure 1. The optimized molecular structures of investigated $\mathrm{Ru}(\mathrm{II})$ complexes.
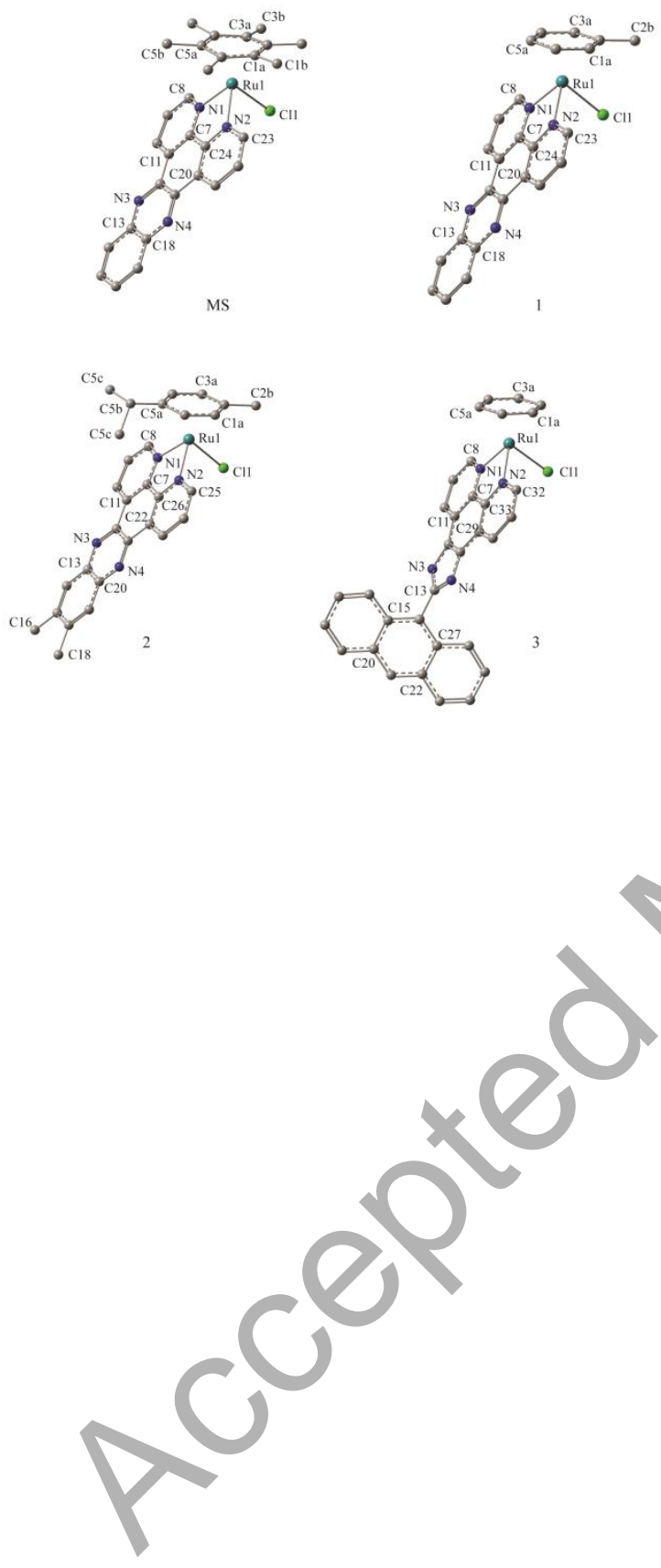
Figure 2. Graphic representations of the calculated HOMO and LUMO orbitals for investigated $\mathrm{Ru}(\mathrm{II})$ complexes.

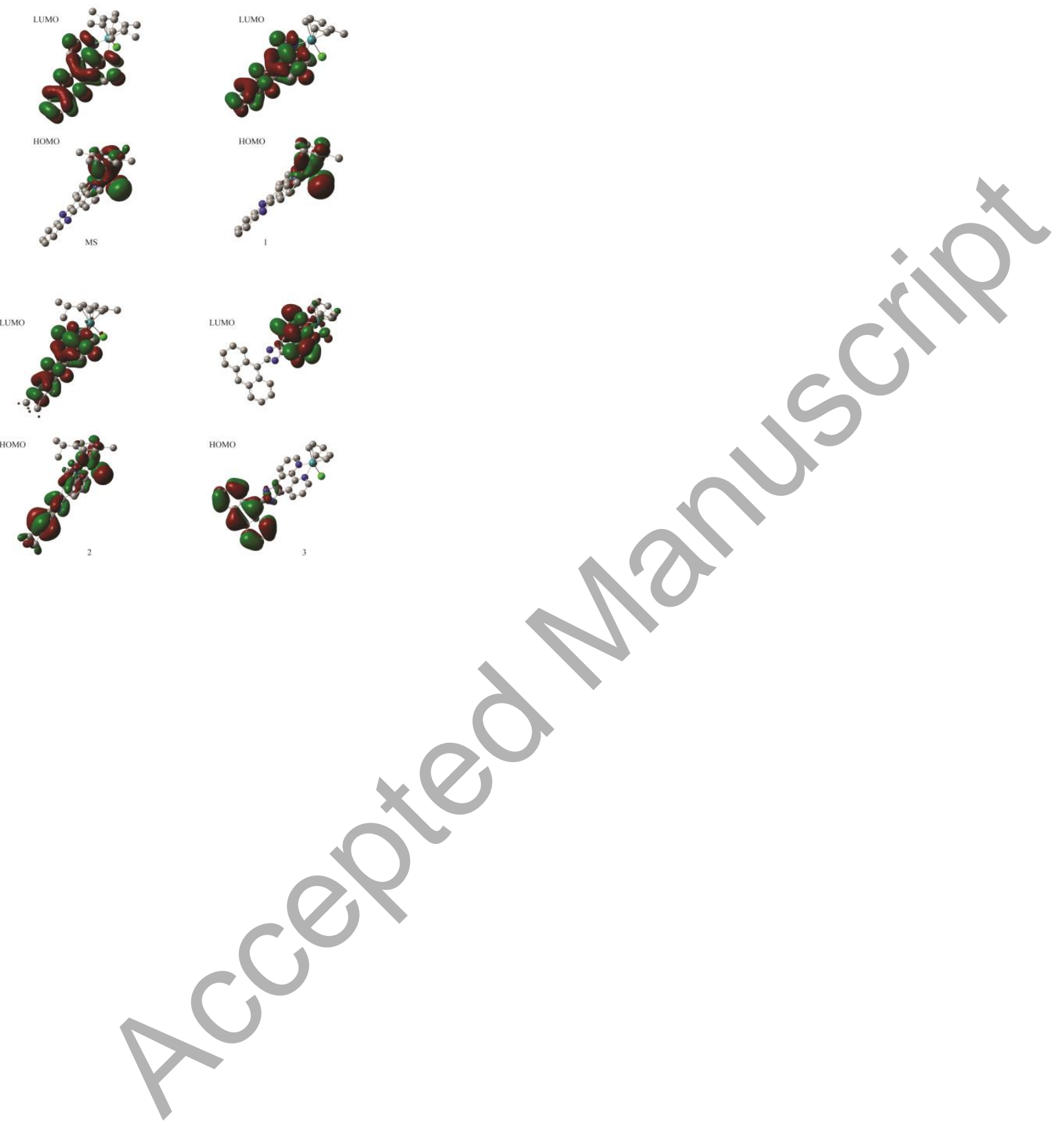


Figure 3. Snapshots of the most preferable binding sites of $\mathrm{Ru}(\mathrm{II})$ complexes with B-DNA.
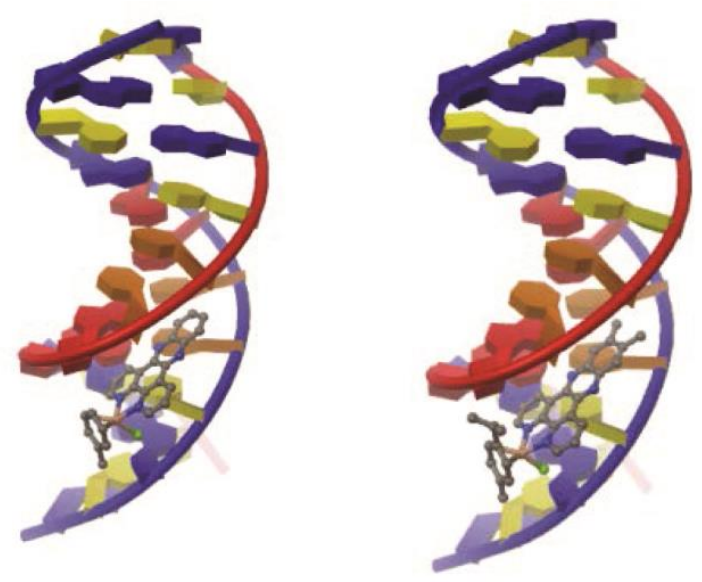

1

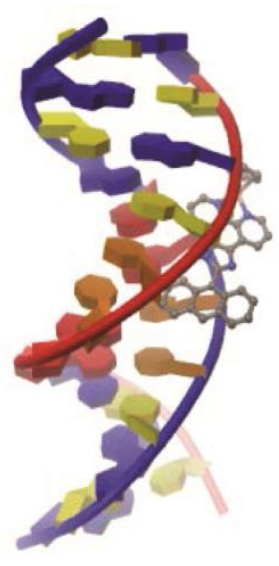

3

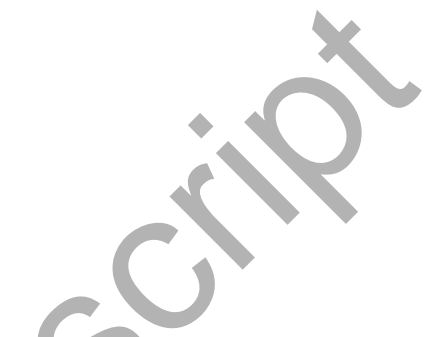


Table 1. DFT calculated bond lengths $(\AA)$ for MS using several functionals and basis sets and corresponding experimental values.

\begin{tabular}{|c|c|c|c|c|c|}
\hline No. & & & $\mathrm{Ru}$-centroid & $\mathrm{Ru}-\mathrm{Cl}$ & $\mathrm{Ru}-\mathrm{N}(\mathrm{dppz})^{*}$ \\
\hline & Experimental data & & 1.703 & 2.411 & 2.112 \\
\hline 1 & B3LYP & $\begin{array}{l}\text { 6-31G(d): C H N Cl } \\
\text { Lanl2dz: Ru }\end{array}$ & 1.819 & 2.422 & 2.116 \\
\hline 2 & B3LYP & $\begin{array}{l}\text { 6-31G(d): Cl H N } \\
\text { 6-311G(d): C } \\
\text { Lanl2dz: Ru }\end{array}$ & 1.807 & 2.419 & 124 \\
\hline 3 & B3LYP & Lanl2dz: All atoms & 1.866 & & 2.082 \\
\hline 4 & B3LYP & $\begin{array}{l}\text { 6-31G(d,p): C H N Cl } \\
\text { Lanl2dz: Ru }\end{array}$ & 1.819 & & 2.116 \\
\hline 5 & B3LYP & $\begin{array}{l}\text { 6-31G++(d): } \mathrm{C} \mathrm{H} \mathrm{N} \mathrm{Cl} \\
\text { Lanl2dz: } \mathrm{Ru}\end{array}$ & & 2.457 & 2.094 \\
\hline 6 & B3LYP & $\begin{array}{l}\text { 6-31G(d): C H N Cl } \\
\text { SDD: } \mathrm{Ru}\end{array}$ & 1.776 & 2.405 & 2.116 \\
\hline 7 & CAM-B3LYP & $\begin{array}{l}\text { 6-31G(d): C HN Cl } \\
\text { Lanl2dz: } \mathrm{Ru}\end{array}$ & 1.793 & 2.402 & 2.111 \\
\hline 8 & TPSSTPSS & $\begin{array}{l}\text { 6-31G(d): C H N Cl } \\
\text { Lan12dz: } \mathrm{Ru}\end{array}$ & 1.753 & 2.408 & 2.127 \\
\hline 9 & B97D & $\begin{array}{l}\text { 6-31G(d): C H N Cl } \\
\text { Lanl2dz: Ru }\end{array}$ & 1.753 & 2.423 & 2.103 \\
\hline 10 & B97D & $\begin{array}{l}\text { 6-31G(d): } \mathrm{H} \mathrm{N} \mathrm{Cl} \\
\text { 6-31G+(d): C } \\
\text { Lanl2dz: } \mathrm{Ru}\end{array}$ & 1.753 & 2.423 & 2.103 \\
\hline 11 & wB97XD & $\begin{array}{l}\text { 6-31G(d,p): C H N Cl } \\
\text { Lanl2dz: Ru }\end{array}$ & 1.746 & 2.406 & 2.120 \\
\hline 12 & wB97XD & $\begin{array}{l}\text { 6-311G(d): C H N Cl } \\
\text { Lanl2dz: Ru }\end{array}$ & 1.733 & 2.409 & 2.125 \\
\hline
\end{tabular}

* Average values 
Table 2. Comparison of the calculated bond lengths $(\AA)$ and angles $\left(^{\circ}\right)$ obtained for the complexes, using wB97XD/6-311G(d) for $\mathrm{C} \mathrm{H} \mathrm{N} \mathrm{Cl}$, and $\mathrm{Lanl} 2 \mathrm{dz}$ for $\mathrm{Ru}$, with the corresponding experimental values.

\begin{tabular}{|c|c|c|c|c|c|}
\hline & \multicolumn{5}{|c|}{ Complexes } \\
\hline & \multicolumn{2}{|c|}{ MS } & 1 & 2 & 3 \\
\hline Distance $(\AA)$ & \multicolumn{2}{|c|}{ Exp. } & \multicolumn{2}{|c|}{ Calc. } & \\
\hline $\mathrm{Ru}-\mathrm{N}(\mathrm{dppz})^{*}$ & 2.112 & 2.125 & 2.115 & 2.115 & 2.112 \\
\hline $\mathrm{Ru}-\mathrm{Cl1}$ & 2.411 & 2.409 & 2.403 & 2.404 & 2.399 \\
\hline Ru-C(arene)* & 2.220 & 2.244 & 2.232 & 2.228 & 2.227 \\
\hline Ru-centroid & 1.705 & 1.733 & 1.726 & & 1.721 \\
\hline \multicolumn{6}{|l|}{ Angle $\left(^{\circ}\right)$} \\
\hline N1-Ru1-N2 & 76.71 & 76.70 & 77.25 & 77.20 & 77.37 \\
\hline $\mathrm{N}(\mathrm{dpp} z)-\mathrm{Ru}-\mathrm{Cl} *$ & 86.90 & 84.21 & 83.44 & 83.83 & 83.71 \\
\hline
\end{tabular}

*Average values 
Table 3. Values of the Fukui function and dual descriptor (a.u.) for $\mathrm{Ru}(\mathrm{II})$ complexes.

\begin{tabular}{|c|c|c|c|c|c|c|c|c|c|}
\hline \multirow{2}{*}{\multicolumn{2}{|c|}{ Complex }} & \multicolumn{2}{|c|}{ Ru } & \multicolumn{2}{|c|}{ Cl } & & & & \\
\hline & & NPA & Mull. & NPA & Mull. & & & & \\
\hline \multirow[t]{5}{*}{ MS } & $f^{+}$ & 0.07 & 0.03 & 0.14 & 0.15 & & & & \\
\hline & $f^{-}$ & 0.24 & 0.07 & 0.22 & 0.22 & & & & \\
\hline & $\Delta f$ & -0.17 & -0.04 & -0.08 & -0.07 & & & & \\
\hline & $f^{0}$ & 0.15 & 0.05 & 0.18 & 0.19 & & & & \\
\hline & & \multicolumn{2}{|c|}{$\mathbf{R u}$} & \multicolumn{2}{|c|}{ Cl } & C21, & & & \\
\hline \multirow[t]{6}{*}{1} & & NPA & Mull & NPA & Mull & NPA & Mull & & \\
\hline & $f^{+}$ & -0.03 & -0.07 & 0.03 & 0.04 & 0.14 & & & \\
\hline & $f^{-}$ & 0.15 & 0.00 & 0.30 & 0.28 & 0.02 & 0.01 & & \\
\hline & $\Delta f$ & -0.18 & -0.07 & -0.28 & -0.24 & 0.13 & 0.09 & & \\
\hline & $f^{0}$ & 0.06 & -0.03 & 0.16 & 0.16 & & 0.06 & & \\
\hline & & \multicolumn{2}{|c|}{$\mathbf{R u}$} & \multicolumn{2}{|c|}{$\mathbf{C l}$} & & & \multicolumn{2}{|c|}{ C14, C19 } \\
\hline \multirow[t]{6}{*}{2} & & NPA & Mull & NPA & Mull & JPA & Mull & NPA & Mull \\
\hline & $f^{+}$ & -0.03 & -0.07 & 0.02 & 0.04 & 0.10 & 0.06 & 0.00 & 0.02 \\
\hline & $f^{-}$ & -0.02 & -0.04 & 0.01 & 0.02 & 0.01 & 0.01 & 0.22 & 0.13 \\
\hline & $\Delta f$ & -0.01 & -0.03 & 00 & 0.02 & 0.08 & 0.05 & -0.21 & -0.11 \\
\hline & $f^{0}$ & -0.02 & -0.05 & 0.02 & 0.03 & 0.05 & 0.03 & 0.11 & 0.07 \\
\hline & & & & \multicolumn{2}{|c|}{ Cl } & \multicolumn{2}{|c|}{ C9, C10, C30, C31 } & \multicolumn{2}{|c|}{$\mathrm{C} 14, \mathrm{C} 21$} \\
\hline \multirow[t]{5}{*}{3} & & NPA & Mull & NPA & Mull & NPA & Mull & NPA & Mull \\
\hline & $f^{+}$ & & -0.08 & 0.04 & 0.06 & 0.09 & 0.06 & 0.02 & 0.01 \\
\hline & $f^{-}$ & -0.01 & -0.03 & 0.00 & 0.01 & 0.01 & 0.01 & 0.16 & 0.08 \\
\hline & $\Delta f$ & -0.02 & -0.05 & 0.03 & 0.05 & 0.09 & 0.06 & -0.11 & -0.07 \\
\hline & & -0.02 & -0.06 & 0.02 & 0.03 & 0.05 & 0.03 & 0.08 & 0.05 \\
\hline
\end{tabular}


Table 4. Cytotoxic effect of the compounds on selected cell lines.

\begin{tabular}{ccccc}
\hline Compounds & \multicolumn{4}{c}{$\mathrm{IC}_{50}$ values $(\mathrm{mM})$} \\
\hline $\mathbf{1}$ & $\mathrm{B} 16$ & $\mathrm{C} 6$ & $\mathrm{U} 251$ & HACAT \\
$\mathbf{2}$ & 0.5 & $>1$ & $>1$ & 0.06 \\
$\mathbf{3}$ & 1 & 0.125 & 0.125 & $>1$ \\
& $>1$ & $>1$ & $>1$ & 0.83 \\
\hline
\end{tabular}

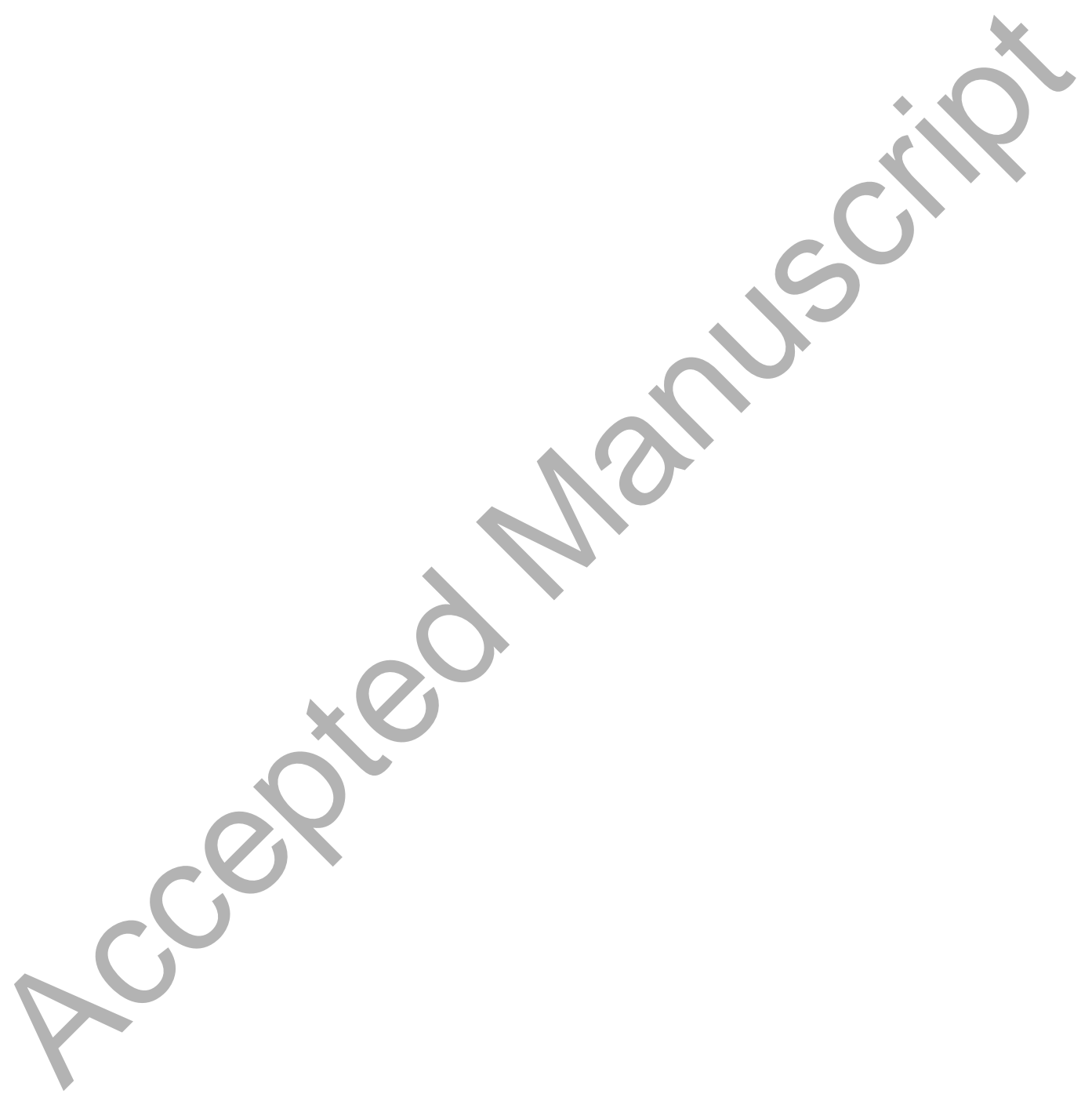

